\title{
PRAGA ORYGINALNA
}

\section{Oak pollen season in selected cities of Poland in 2019}

\section{Katarzyna Dąbrowska-Zapart', Kazimiera Chłopek', Małgorzata Malkiewicz², Krystyna Piotrowska-Weryszko³, Daniel Kotrych ${ }^{4}$, Ewa Kalinowska ${ }^{5}$, Anna Rapiejk0 ${ }^{5,6}$, Grzegorz Siergiejk0 ${ }^{7}$, Dariusz Jurkiewicz, Kornel Szczygielski ${ }^{8}$, Agnieszka Lipiec ${ }^{9}$}

${ }^{1}$ Faculty of Natural Sciences, Institute of Earth Sciences, University of Silesia, Poland

2 Department of Palaeobotany, Institute of Geological Sciences, University of Wroclaw, Poland ${ }^{3}$ Subdepartment of Aerobiology, Department of Botany and Plant Physiology, University of Life Sciences in Lublin, Poland

${ }^{4}$ Department of Orthopedics and Traumatology, Pomeranian Medical University of Szczecin, Poland ${ }^{5}$ Allergen Research Center, Warsaw, Poland ${ }^{6}$ Medical University of Warsaw, Poland ${ }^{7}$ Pediatrics, Gastroenterology and Allergology Department, University Children Hospital, Medical University of Bialystok, Poland

${ }^{8}$ Department of Otolaryngology with Division of Cranio-Maxillo-Facial Surgery in Military Institute of Medicine, Warsaw, Poland

${ }^{9}$ Department of Prevention of Environmental Hazards and Allergology, Medical University of Warsaw, Poland

\section{Abstract:}

The study compares the oak pollen seasons in Bialystok, Bydgoszcz, Sosnowiec, Lublin, Olsztyn, Opole, Piotrkow Trybunalski, Szczecin, Warsaw, Wroclaw and Zielona Gora in 2019. The investigations were conducted using the volumetric method. The oak season started in all measurement sites between April $6^{\text {th }}$ (Szczecin) and April 24 $4^{\text {th }}$ (Lublin and Piotrkow Trybunalski). The peak values of seasonal pollen count occurred between April $25^{\text {th }}$ and May $2^{\text {id }}$. The highest daily pollen count was recorded in Lublin $\left(273 \mathrm{P} / \mathrm{m}^{3}\right)$ and the lowest pollen count in Bialystok $\left(23 \mathrm{P} / \mathrm{m}^{3}\right)$. The highest annual totals were recorded in Lublin, Piotrkow Trybunalski and Warsaw. The most days with concentration equal to or above $16 \mathrm{P} / \mathrm{m}^{3}$, causing symptoms in many allergic patients, were recorded in Lublin and Warsaw. Days with concentration equal to or above $91 \mathrm{P} / \mathrm{m}^{3}$, which causes allergy of all sensitized patients, were the most frequent in Lublin, Piotrkow Trybunalski and Warsaw.

Key words: allergens, pollen count, oak (Quercus), Poland, 2019

0 aks belong to the beech family (Fagaceae), two species of which grow wild in Poland, with pollen period varying by about 2 weeks: pedunculate oak (Quercus robur L.) and sessile oak (Q. petraea Liebl.). Due to different pollination terms of pedunculate and sessile oak, exposure to oak pollen allergens may be long (up to 4 weeks), but usually one species dominates in a given area.

Pedunculate oak is common across the country, often growing in mixed forests and in clean oak forests, parks, along roads and in the mountains up to $600-700 \mathrm{~m}$ a.s.l. It usually blooms at the turn of
April and May and throughout May. Pedunculate oak blooms about 2 weeks before sessile [1,2]. Sessile occurs in forests, except for mountainous areas and the north-eastern part of the country, it is also popular in parks [3]. An alien species, often found in forests and parks throughout Poland is red oak (Q. rubra L.), which grows faster than other oak species [4].

Oak pollen next to birch pollen, alder, ash and hazel is considered as one of the most crucial tree pollen allergens $[5,6]$. The threshold value for clinical symptoms for Quercus pollen grains for the many of sensitised patients is visible during exposure to the 
concentration of 16 pollen grains in $1 \mathrm{~m}^{3}$ of air, while the clinical symptoms for the most of sensitised patients is visible during exposure to the concentration of 91 pollen grains in $1 \mathrm{~m}^{3}$ of air [7]. The cross-reactions of oak pollen allergens with pollen from other Fagaceae species and with pollen from Corylaceae and Betulaceae species also are known [8].

Aim

The aim of the study was to compare the oak pollen season in Bialystok, Bydgoszcz, Sosnowiec, Lublin, Olsztyn, Opole, Piotrkow Trybunalski, Szczecin, Warsaw, Wroclaw and Zielona Gora in 2019.

\section{Material and method}

The measurements of the pollen concentration in the study sites were performed with the volumetric method using Burkard and Lanzoni pollen samplers. Microscopic observations were performed on preparations obtained in a 7-day cycle with assessment of 24-hour periods. The results were expressed as the number of pollen grains in $1 \mathrm{~m}^{3}$ of air per day $\left(\mathrm{P} / \mathrm{m}^{3}\right)$. The start of the season was defined as a date when $1 \%$ of the seasonal cumulative pollen count was trapped and the end of the season when cumulative pollen count reached $99 \%$. The total pollen count over this period was expressed by the symbol SPI (Seasonal Pollen Index). The course of the pollen seasons in each city is shown in the graphs (figs 1-5).

\section{Results and discussion}

In 2019, the oak pollen season started between April $6^{\text {th }}$ (Szczecin) and April 24 $4^{\text {th }}$ (Lublin and Piotrkow Trybunalski) and ended up in the second or third decade of May (tab. 1, figs 1-5). The earliest pollen season of oak began in Szczecin, already in April, much earlier than in 2018 (April 17 ${ }^{\text {th }}$ ) [9]. The latest pollen season of oak began in Lublin and Piotrkow Trybunalski, as it was not until April 24 (tab. 1, fig. 3), a few days later than in the previous season [9]. In Szczecin a very long pollen season was found, which was 46 days (tab. 1). The highest oak pollen concentrations were detected in the third decade of

Table 1. Characteristics of Quercus pollen season in 2019.

\begin{tabular}{|c|c|c|c|c|c|}
\hline Site & $\begin{array}{l}\text { Duration of pollen season } \\
\text { (number and days) }\end{array}$ & $\begin{array}{c}\text { Peak value }\left[\mathrm{P} / \mathrm{m}^{3}\right] \text { and } \\
\text { peak date }\end{array}$ & $\begin{array}{l}\text { Seasonal Pollen Index } \\
\text { (SPI) }\end{array}$ & $\begin{array}{c}\text { Days } \\
\geq 16 \mathrm{~g} / \mathrm{m}^{3} \text { * }\end{array}$ & $\begin{array}{c}\text { Days } \\
\geq 91 \mathrm{~g} / \mathrm{m}^{3 * *}\end{array}$ \\
\hline Bialystok & $\begin{array}{c}17.04-20.05 \\
34\end{array}$ & $\begin{array}{c}23 \\
29.04\end{array}$ & 172 & 0 & 0 \\
\hline Bydgoszcz & $\begin{array}{c}17.04-25.05 \\
39\end{array}$ & $\begin{array}{c}56 \\
4.05\end{array}$ & 474 & 8 & 0 \\
\hline Sosnowiec & $\begin{array}{c}9.04-19.05 \\
41\end{array}$ & $\begin{array}{c}68 \\
27.04\end{array}$ & 371 & 5 & 0 \\
\hline Lublin & $\begin{array}{c}24.04-20.05 \\
27\end{array}$ & $\begin{array}{l}273 \\
2.05\end{array}$ & 1928 & 22 & 7 \\
\hline Olsztyn & $\begin{array}{c}23.04-21.05 \\
29\end{array}$ & $\begin{array}{c}45 \\
2.05\end{array}$ & 444 & 10 & 0 \\
\hline Opole & $\begin{array}{c}14.04-14.05 \\
31\end{array}$ & $\begin{array}{c}142 \\
25.04\end{array}$ & 711 & 10 & 2 \\
\hline Piotrkow Trybunalski & $\begin{array}{c}24.04-18.05 \\
25\end{array}$ & $\begin{array}{l}143 \\
2.05\end{array}$ & 1342 & 11 & 4 \\
\hline Szczecin & $\begin{array}{c}6.04-21.05 \\
46\end{array}$ & $\begin{array}{c}33 \\
25.04\end{array}$ & 295 & 5 & 0 \\
\hline Warsaw & $\begin{array}{c}23.04-19.05 \\
27\end{array}$ & $\begin{array}{l}112 \\
2.05\end{array}$ & 1123 & 19 & 2 \\
\hline Wroclaw & $\begin{array}{c}15.04-14.05 \\
29\end{array}$ & $\begin{array}{c}118 \\
25.04\end{array}$ & 690 & 15 & 1 \\
\hline Zielona Gora & $\begin{array}{c}8.04-11.05 \\
34\end{array}$ & $\begin{array}{c}97 \\
25.04\end{array}$ & 770 & 17 & 1 \\
\hline
\end{tabular}

* symptoms present in many patients, ${ }^{* *}$ symptoms present in most patients. 


\section{PRACA ORYEINALNA}

Figure 1. Oak pollen count in Bialystok and Bydgoszcz in 2019.

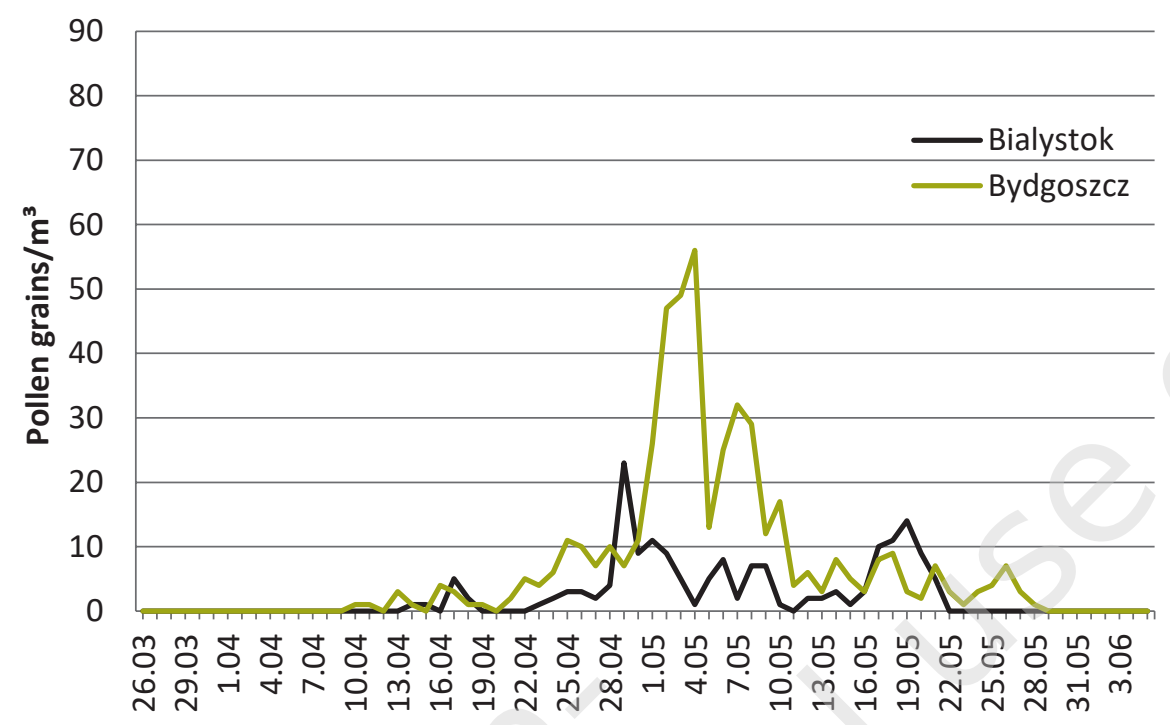

Figure 2. Oak pollen count in Sosnowiec and Zielona Gora in 2019.

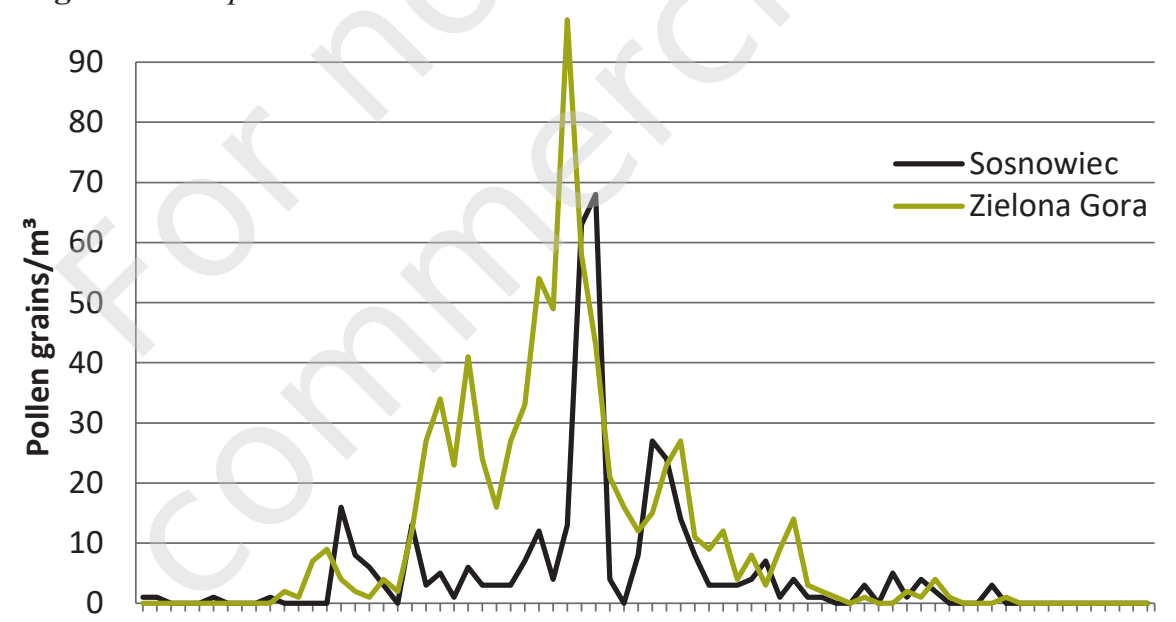

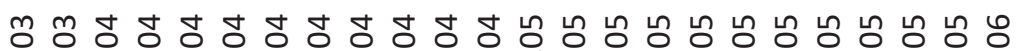
ம்

Figure 3. Oak pollen count in Lublin, Opole and Piotrkow Trybunalski in 2019.

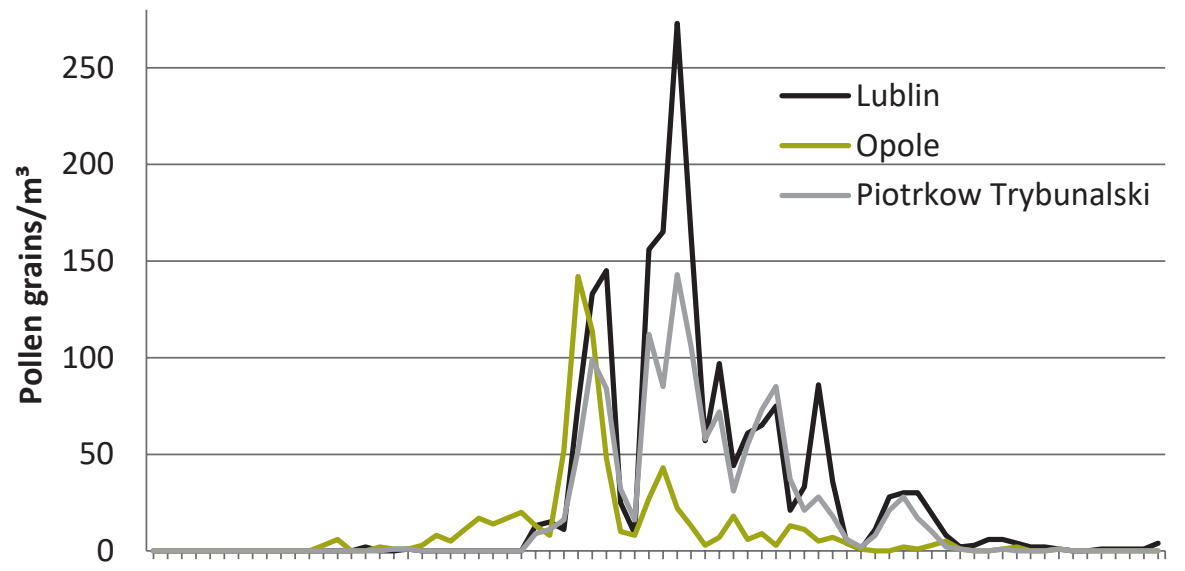

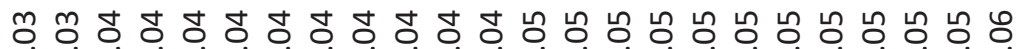
ஸे ஹं 
Figure 4. Oak pollen count in Szczecin and Olsztyn in 2019.

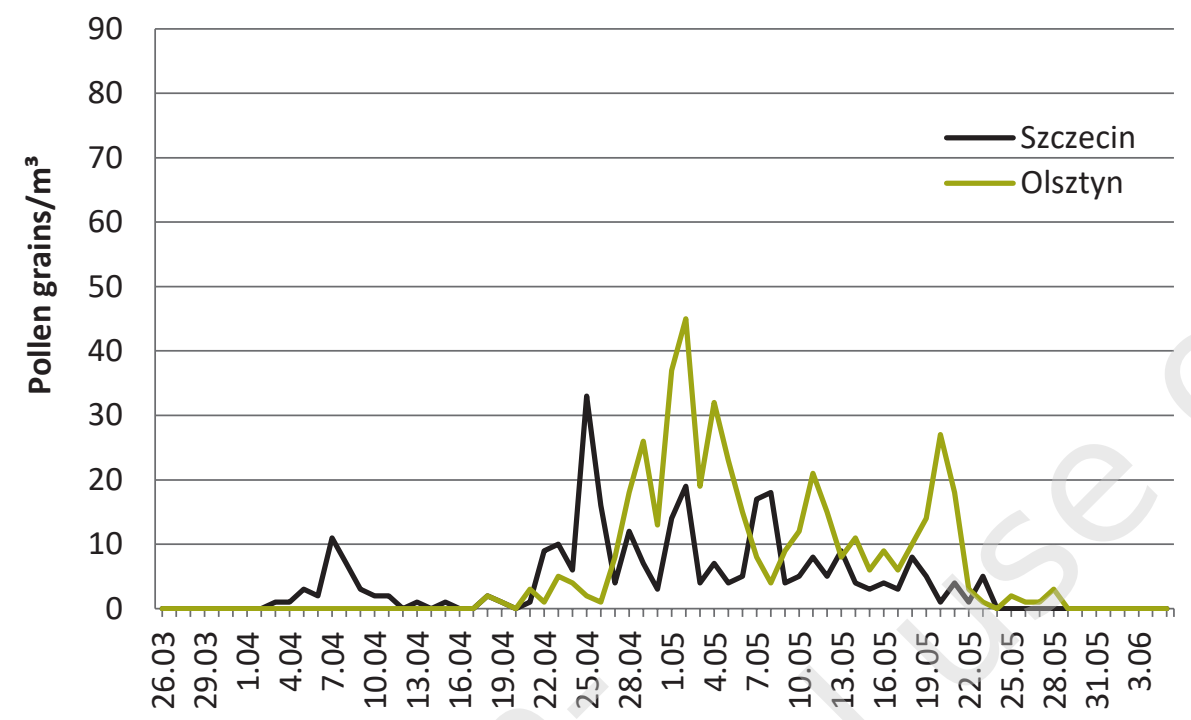

Figure 5. Oak pollen count in Warsaw and Wroclaw in 2019.

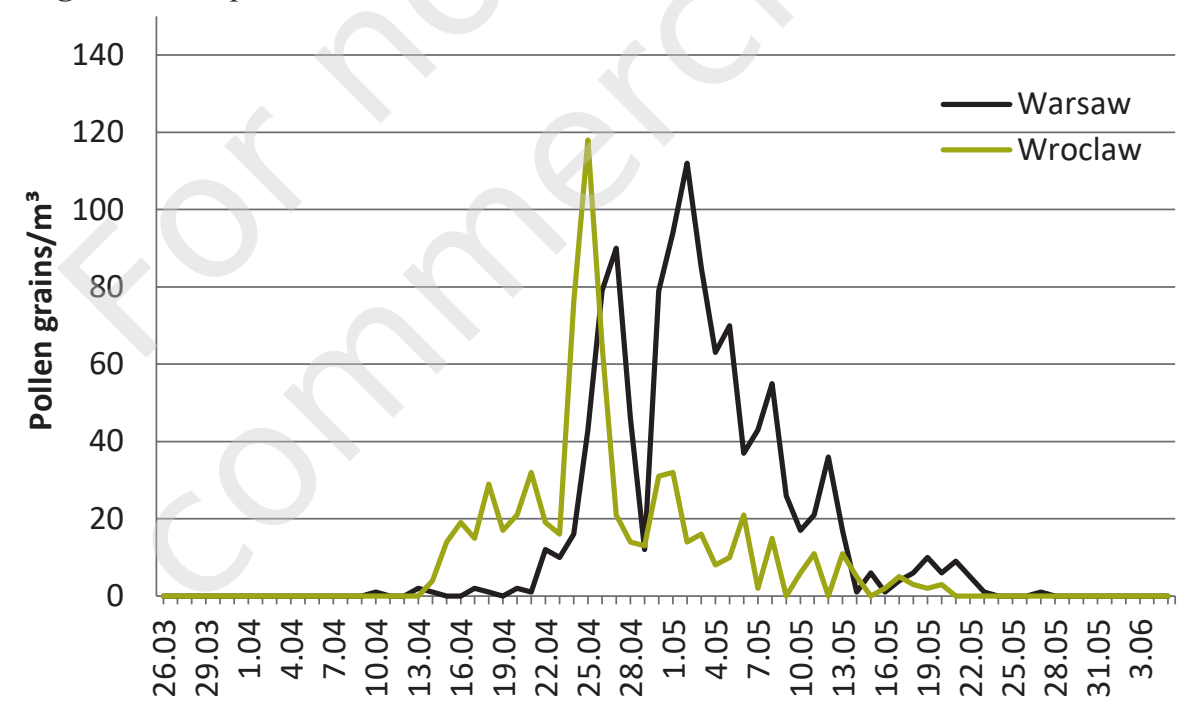

April and in the first days of May in all analyzed cities (tab. 1). The highest daily pollen count was recorded in Lublin - $273 \mathrm{P} / \mathrm{m}^{3}$, Piotrkow Trybunalski - $143 \mathrm{P} / \mathrm{m}^{3}$ and in Warsaw $-112 \mathrm{P} / \mathrm{m}^{3}$ on the same day in all three cities (May 2 ${ }^{\text {nd }}$ ) (fig. 3, 5). While the lowest concentration of pollen was found in Bialystok - it was only $23 \mathrm{P} / \mathrm{m}^{3}$ (fig. 1).

In 2019, the sums of oak pollen grains were in the range of 172-1928; the highest sum of grains was noted in Lublin (1928), Piotrkow Trybunalski (1342) and Warsaw (1123) and the lowest totals were recorded in Bialystok (172) and Szczecin (295) (tab. 1).

The highest oak pollen risk (above $91 \mathrm{P} / \mathrm{m}^{3}$ ) occurred in Lublin (7 days) and Piotrkow Trybunalski (4 days) (tab. 1). In the other cities this value was
0-2 days (tab. 1). For most of the cities these are lower values than those recorded in 2018 [9] and 2017 [10].

\section{Conclusions}

1. In 2019, the oak pollen season in all the analysed cities started between April $6^{\text {th }}$ and April 24 ${ }^{\text {th }}$. The pollen season duration at the investigated monitoring sites was 25-46 days (on average 33 days).

2. The highest concentrations of oak pollen were recorded in Lublin, Piotrkow Trybunalski and Warsaw, whereas the lowest concentrations were noted for Bialystok.

3. The peak values of seasonal pollen count occurred between April $25^{\text {th }}-$ May $2^{\text {nd }}$ in all cities. 


\section{PRAGA ORYEINALNA}

4. The highest oak pollen allergen risk occurred in Lublin and Piotrkow Trybunalski.

\section{References}

1. Rutkowski L. Klucz do oznaczania roślin naczyniowych Polski niżowej. PWN, Warszawa 2004

2. Rapiejko P. Alergeny pyłku roślin. Medical Education, Warszawa 2012.

3. Bugała W. Drzewa i krzewy. Państwowe Wyd. Rolnicze i Leśne, Warszawa 2000.

4. Seneta W, Dolatowski J. Dendrologia. PWN, Warszawa 2008.

5. Bohadana AB, Massin N, Wild P et al. Symptoms, airway responsiveness, and exposure to dust in beech and oak wood workers. Occup Environ Med 2000, 57(4): 268-273.

6. Rapiejko P. Sezon pylenia leszczyny $i$ olszy $w$ Warszawie w 2008 roku (doniesienie wstepne). Alergia 2008, 1: 49-50.

7. Burge HA. Monitoring for airborne allergens. Ann Allergy 1992, 69: 9-21.

8. Spieksma FThM, Frenguelli G. Allergenic significance of Alnus (alder) pollen. In: Allergenic pollen and pollinosis in Europe. Blackwell Sci Pub 1991: 85-87.

9. Sulborska A, Weryszko-Chmielewska EK, Piotrowska-Weryszko A et al. The oak pollen concentration in the air of selected cities in Poland in 2018. Alergoprofil 2018, 14(3): 67-71.
10. Puc M, Myszkowska D, Chłopek Ket al. Oak pollen in the air of Poland in 2017. Alergoprofil 2017, 13(3): 124-128.

ORCID

K. Dąbrowska-Zapart - ID - orcid.org/ 0000-0002-8976-7739

M. Malkiewicz - ID - orcid. org/0000-0001-6768-7968

K. Piotrowska-Weryszko - ID - orcid.org/ 0000-0003-3827-3218

D. Kotrych - ID - orcid.org/0000-0003-4221-2944

E. Kalinowska - ID - orcid.org/ 0000-0003-4821-6882

A. Lipiec - ID - orcid.org/0000-0003-3037-2326

\section{Author's contributions:}

Dąbrowska-Zapart K: 40\%; Chłopek K: 10,5\%; other authors: 5,5\% each. Conflict of interests: The authors declare that they have no competing interests.

Ethics: The contents presented in this paper are compatible with the rules the Declaration of Helsinki, EU directives and standardized requirements for medical journals.

Research in Bialystok, Bydgoszcz, Piotrkow Trybunalski, Opole, Zielona Gora, Warsaw funded by Allergen Research Center Ltd. (Ośrodek Badania Alergenów Środowiskowych Sp. z 0.0.)

\section{Corresponding author:}

Katarzyna Dąbrowska-Zapart, MD, PhD

Faculty of Natural Sciences, Institute of Earth Sciences, University of Silesia

41-200 Sosnowiec, Będzińska 60

phone: (32) 368-94-77

e-mail: katarzyna.dabrowska-zapart@us.edu.pl 